\title{
THEORY AND PRACTICE OF STATE INTERVENTION: ITALY, SOUTH KOREA AND STAGES OF ECONOMIC DEVELOPMENT
}

\author{
Roberto Cardinale \\ The Bartlett Faculty of the Built Environment, University College London \\ 1-19 Torrington Place, Fitzrovia, London WC1E 7HB \\ $\underline{\text { Roberto.cardinale.14@ucl.ac.uk }}$
}

\begin{abstract}
Strategies of economic development differ widely in terms of approaches to State intervention. However, across countries, certain policies tend to prevail at specific stages of development. For example, the Italian and South Korean cases, analysed in this paper, suggest the prevalence of sectoral policies at early stages, followed by a reorientation towards microeconomic policies at later stages. The paper interprets this trend through the viewpoints of three theoretical perspectives: structural, allocative and evolutionary. The historical and theoretical analysis of the paper shows that, even if each stage of development is characterised by the prominence of a specific policy over others, a mix of policies is pursued at each stage. In addition, the functions of each policy approach vary depending on the stage. This finding highlights unexpected linkages between theory and policy, and the need to consider different theoretical perspectives to understand the multifaceted character of economic policy.
\end{abstract}

\section{JEL Classifications}

O14; O24; O25; O38; P16; P51

This research started during a research visit to Sungkyunkwan University, Seoul, which was made possible by a scholarship awarded by the Catholic University of Milan. It continued in subsequent years thanks to the support of the Ermenegildo Zegna Founder's Scholarship and University College London. The author would like to thank the organisers and participants at 
the Schumpeter conference in Korea for the opportunity to present this paper in attenuated form and for the useful feedback received.

\section{Introduction}

Italy and South Korea experienced successful paths of economic development in the last seven decades, and followed broadly similar policy approaches at each stage of development ${ }^{1}$. In the early stages, the creation and expansion of basic manufacturing and intermediate sectors ${ }^{2}$ dominated economic policy as these were considered pivotal for industrial upgrade and longterm economic growth. Foreign trade played an essential role, making possible the accumulation of surpluses and reinvestment in strategic sectors. At an intermediate stage of development, the major objectives of growth had been reached although margins for catchingup persisted in high-tech sectors, and this required the adoption of mixed approaches. Whereas technology-push approaches were still adopted to leapfrog in high-tech sectors, liberalisation became the dominant paradigm of economic policy as it was ideal to exploit the comparative advantages recently achieved in capital-intensive sectors. In the latest stage of development, when the economy was at the technological frontier in certain sectors, innovation became the key element to avoid being overtaken by competitors. However, at this stage, although innovation is pursued through a mix of technology-push and market pull approaches, the latter are often privileged because of fundamental uncertainty and the greater flexibility they entail.

The current debate on the relationship between stages of development and economic policies does not capture the rationale for the adoption of different policy approaches at each stage. In fact, the allocative view suggests the adoption of microeconomic policies at all stages, as these make it possible to use factors that are abundant in the economy and thus exploit existing comparative advantages (Baldwin, 1969; Krugman, 1981; Lin, 2009; Timmer and Tsirmai, 2000; Samuelson, 1948). A contrasting view argues that each stage requires a different policy approach (Chang, 1994; Furtado, 1964; Janeway, 2012; List, 1885; Peneder 2003; Saviotti and Pyka 2004). It suggests that, in early stages, sectoral policies are pivotal for defying current comparative advantage and developing new ones in high value-added sectors.

\footnotetext{
${ }^{1}$ The paper follows Rostow's (1990) theoretical framework for classifying the stages of economic development. In particular, the early stage is here considered as the 'take off', the intermediate stage as the 'drive to maturity', and the late stage as the 'age of high mass consumption'.

${ }^{2}$ Intermediate sectors are here intended as sectors for the production of technology-intensive intermediate goods (e.g. steel, petrochemicals, energy, infrastructure, machine tools, and electronics).
} 
In advanced stages, microeconomic policies such as trade liberalisation make it possible to exploit the advantage achieved and prevent being overtaken by competitors.

The paper contributes to the current debate in two main ways. First, it argues that sectoral and microeconomic policies coexist at all stages, although the former are more prominent in early stages whilst the latter are so in subsequent stages. Their coexistence at all stages can be interpreted as reflecting the need to pursue different and complementary policy objectives at any given time. For instance, in early stages, microeconomic policies help exploit current comparative advantages, and this is pivotal for capital accumulation and reinvestment in sectoral plans of economic upgrade.

Second, the paper shows that each policy approach (microeconomic and sectoral) may serve both developmental or allocative functions, depending on the stage at which they are adopted. In fact, sectoral approaches in early stages are usually adopted for developmental purposes, namely to expand and upgrade production; in intermediate stages, to pursue both developmental and efficiency objectives, respectively for catching up in high-tech sectors and to implement plans of industrial restructuring; in late stages, to control strategic sectors and trigger large-scale innovations. In contrast, microeconomic approaches (such as selective opening to foreign trade) are pivotal for capital accumulation in early stages, as these have the function to exploit existing comparative advantages in labour-intensive sectors; to pursue allocative efficiency in domestic markets and exploit comparative advantages in capitalintensive sectors in intermediate and late stages; and to trigger incremental innovation in late stages.

Taken as a whole, the analysis of this paper provides a framework to understand the coexistence of different policy approaches at different stages of development, and their different functions at each stage. To explore this issue, it is necessary to examine the theoretical perspectives inspiring each policy approach ${ }^{3}$. Structural dynamics theories help explain the role of sectoral policies for structural change. Allocative theories help understand the role of microeconomic policies for allocative efficiency both in domestic and international markets. Evolutionary theories shed light on the role of microeconomic and sectoral policies for innovation under fundamental uncertainty. Taken together, the different theoretical

\footnotetext{
${ }^{3}$ See Dasgupta (1987) on the relation between economic theories and stages of development, and Scazzieri and Witt (2005) on the link between economic theories and the dynamics of production patterns.
} 
perspectives make it possible to explore the multi-objective character of economic policy at each stage of development, and the rationale for policy change in the transition across stages.

The paper is structured as follows. Section 2 reconstructs the rationale for State intervention at every stage of development in terms of theoretical perspectives - structural, allocative and evolutionary. Section 3 sketches the evolution of Italian and South Korean economic policy since the 1950s. Section 4 discusses the main findings and brings the paper to close.

\section{Theoretical perspectives and stages of development: a framework}

\subsection{The sectoral approach and structural dynamics theories}

Theories of structural dynamics investigate long-term economic dynamics through a sectoral approach. In other words, they analyse changes in the economic system as a result of changes in the proportions between sectors (Baranzini and Scazzieri, 1990; Leontief, 1991; Löwe, 1976; Pasinetti, 1981; Quadrio Curzio, 1986; Scazzieri, 2009; Silva and Teixeira, 2008). Whereas this approach deals with State intervention only marginally, several contributions provide, directly or indirectly, useful starting points for understanding the rationale for State intervention in Italy and South Korea's early phases of industrialisation.

This section argues that structural dynamics theory's meso (sectoral) analysis is particularly useful for economies at early stage of industrialisation, as these typically suffer from underdeveloped intermediate phases of production. The main deficiencies include shortage of infrastructure for the provision of raw materials, the lack of advanced technologies in basic manufacturing, unbalanced growth and technological gaps among interdependent sectors. Sectoral analysis helps identifying such deficiencies, which sectoral policy can successfully compensate, as the Italian and South Korean cases will show.

The importance of sectoral differentiation for structural change and economic growth emerges as a hallmark in structural dynamics theories. For instance, Quadrio Curzio (1986; 1999) highlights the constraints that certain inputs exercise on the production process, and their implications for economic dynamics. In particular, he argues that raw materials are only partially substitutable, and that attempts to replace them in conditions of domestic scarcity often brings to changes in the production processes, particularly in technology. The coexistence 
of old and new technologies, and their potential incompatibility, thus poses an important constraint to economic growth.

Changes in technology, together with changes in demand, are the two fundamental factors that determine structural changes in Pasinetti's $(1981,1993)$ multi-sectoral model. In this approach, structural changes occur because of the differentiated impact of technological change in different sectors, which in turn require the sectoral composition of demand to be compatible with such changes. This approach thus suggests that sectoral patterns of technology and demand are key variables for structural change and economic growth. As such, it can provide a starting point to think about policies that are compatible with such patterns, e.g. concerning the decisions of investment allocation among different sectors (Araujo and Teixeira, 2002).

According to Spaventa (1960; 2013 [1959]), the dynamics of technological diffusion by means of sectoral interdependence depend on the stages of economic development. However, he warns of the potential negative effects of the adoption of imported technologies for developing economies. In particular, he suggests that the latter could be exposed to the risk of developing a dual economy when technology is imported from advanced economies.

The importance of sectoral differentiation for a balanced economic growth emerges also in Löwe's (1976) model of production. In his analysis based on horizontally interdependent sectors, he distinguishes between sectors with higher or lower systemic relevance. In particular, he emphasizes the role of the 'machine-tools' sectors as inputs for a wide range of subsectors, including those producing final goods. According to Löwe, capital accumulation on 'machine-tools' sectors is the first step to induce output increases in the interdependent subsectors, and generate balanced economic growth.

Important contributions to sectoral analysis also derive from empirical and historical works in the study of early-stage economic development (Lewis, 1954; Nurkse, 1953; Rosenstein-Rodan, 1961), and from the 'structuralist' school of thought (Furtado, 1964; Prebisch, 1950). The structuralist approach, for example, emphasises the strategic relevance of intermediate sectors, pointing out that their underdevelopment is a constraint for early-stage economies. According to Furtado (1964), the underdevelopment of intermediate phases of production such as basic manufacturing has two main negative effects: the impossibility of benefiting from positive spillovers deriving from their high technological content, and the dependence on the imports of intermediate goods. Several other contributions share this view 
and highlight the systemic importance of intermediate sectors, particularly in early-stage economies (Dobb, 1960; Naqvi, 1963; Sen, 1960).

In conclusion, structural dynamics theories provide a lens to understand the importance of sectoral policies in early stages. In fact, sectoral policies make it possible to overcome rigidities and constraints - in the provision of critical inputs and in intermediate phases of production - that typically occur in early stages. These constraints, in turn, affect both the efficiency of markets at the microeconomic level as well as the pursuit of macroeconomic objectives (Mamalakis, 1969; 1992). Integrating value chains and overcoming these structural deficiencies were priorities of both the Italian and South Korean economies in their early stages. Large-scale investments for the creation and expansion of intermediate sectors (e.g. basic manufacturing) increased market efficiency as critical inputs were provided to final producers in several sectors of the economy. Furthermore, they created new comparative advantages in high value-added sectors, contributing positively to industrial upgrade, structural change and sustained economic growth.

However, the structural approach is also useful to understand more advanced stages. In particular, it highlights sectoral differences, and in particular the strategic nature of certain sectors. The Italian and South Korean cases will show that sectoral policies are still adopted in sectors of systemic relevance, both through public expenditure and direct State ownership of key firms. In fact, the high degree of interdependence with the rest of the economy makes it possible for the State to pursue policy objectives such as innovation and economic development at the technological frontier.

\subsection{The microeconomic approach and allocative theories}

Allocative theories explore how to best allocate exiting resources in a given economic system. They conceive of individual choices of consumers and producers as the key drivers for economic change. This brings the analysis to adopt a microeconomic, market level approach, which is the playfield for economic agents (Arrow and Hahn, 1983). Because of the focus on how existing resources are allocated (Debreu, 1959), this approach is a static one, which does not address structural change. It can be argued that the static perspective that characterises allocative approaches is more suitable for understanding economies at intermediate and late stages of development. In fact, in a context in which extensive structural changes have 
occurred, or at least have been initiated, the priority is how to best allocate existing resources rather than creating the conditions for the economy to grow on a sustained basis.

In allocative approaches, competition among economic agents is the key element for maximising allocative efficiency. Competition, in fact, makes it possible for efficient producers to replace inefficient ones while minimizing the price for final consumers. As a result, State intervention in the market is seen as undesirable because it causes distortions on prices and quantities set by market mechanisms (Arrow, 1969). However, it is well known that State intervention can be justified, in an allocative perspective, by market failures, and in particular negative externalities, positive externalities and natural monopoly (Pigou, 1920).

Within the allocative perspective, however, externalities do not necessarily justify State intervention. For example, by considering the firm perspective instead of the market perspective alone, Coase (1960) argued that vertical integration of firms can be an effective solution to minimize externalities, as it brings firms rather than third parties to be affected by the externality, thus forcing them to take adequate measures to deal with it. Moreover, Stiglitz (1989) argues that State failures can occur more often than market failures, given the lack of information by State officials and the mosaic of interests influencing public policies. Hence, he suggests that, in cases in which a strong influence may be exercised by special interests, State intervention should be limited. The exception is intervention to encourage strong competition in the economy, as this increase consumers' welfare. According to this perspective, regulation should be based and take advantage of the liberalisation of both internal markets and foreign trade.

The implications of foreign trade for allocative efficiency have been traditionally explained by Heckscher-Ohlin-Samuelson model, which builds upon Ricardo's theory of comparative advantages (Heckscher et al., 1991). The model assumes that comparative advantages of countries depend mainly on production factors. In particular, countries export goods and services that use domestically abundant factors of production, whilst importing those that use domestically scarce factors. Subsequent contributions have also shed light on the positive implications of foreign trade liberalisation for allocative efficiency. For instance, Krugman (1981) argues that market opening is beneficial for countries because of two main effects deriving specifically from increasing intra-industry competition: increasing product specialisation, which is beneficial for consumers, and increasing economies of scale, which make it possible for firms to decrease costs and increase scale of production, thus becoming more efficient. 
In conclusion, it can be argued that the policies suggested by allocative theories tend to be relevant at advanced stages of development. In fact, in domestic markets, liberalisation can be seen as bringing to a more efficient allocation of resources. This outcome is desirable only after having achieved key objectives of development, for instance balanced economic growth and adequate development of key sectors such as infrastructure and other intermediate and high-tech sectors. A similar logic concerns foreign trade. Trade liberalization leads to efficiency improvements because it exposes the most competitive sectors to international markets, providing the opportunity to increase the scale of production and distribution (Krugman, 1981). However, this policy is desirable mainly if goods and services exported are technology-intensive (both final and intermediate), which are abundant in advanced economies. The desirability of this policy can be explained by the favourable terms of trade, which are unlikely to occur when countries export mainly low value-added, labour-intensive goods (Amable, 2000; Fagerberg, 2000). However, the practice of economic policy suggests that allocative policies have played an important role also in earlier stages, along with sectoral policies. In fact, the Italian and South Korean cases will show that exploitation of comparative advantages, even though in low value-added sectors, was pivotal for the generation of surpluses that could be subsequently invested in higher value-added sectors.

\subsection{The microeconomic approach and evolutionary theories}

Evolutionary theories explore how technological and institutional change affect the economy in all its main components, for instance production, consumption, employment, and trade. The theory assumes an economic system undergoing continuous change, thus emphasizing the dynamic rather than static nature of the economy. The introduction of a dynamic perspective has also implied a strong element of uncertainty (Nelson and Winter, 1982; Foster, 1997), particularly regarding technological exploration. This section argues that the assumption of fundamental uncertainty in evolutionary theories make them suitable for the interpretation of economies at late stages of development. In fact, fundamental uncertainty is a typical element of economies at the technological frontier, which constantly face decisions over the innovation paths to undertake, whose outcomes are uncertain.

In this context, innovation is a key variable (Nightingale, 2001; Witt, 2003), as it makes it possible for economies not to be overtaken by foreign competitors. Most of the contributions suggest that innovation should be pursued through microeconomic policies, as these limit the 
effects of uncertainty (Moreau, 2004). According to some, however, the paths to innovation determined at the microeconomic level might be able to influence also macroeconomic variables such as aggregate income and labour productivity (Chiaramonte and Dosi, 1993).

In evolutionary theories, economic policy is conceived from two main viewpointsallocative and structural. The allocative viewpoint suggests the adoption of "piecemeal policy" approaches, also defined as "adaptive policy-making" (Metcalfe, 1994). These approaches conceive of policy-making as a constant mutual interaction between policy-makers and policy results (Lipsey and Fraser, 1997). This logic suggests that only incremental policy changes create the conditions for testing the policy effects on a small scale, thus to readjust or modify the original policy direction. This mechanism of learning-by-doing makes it possible not only to achieve policy goals such as innovation incrementally, but also to avoid undesirable public policy failures, e.g. resources misallocation.

The allocative view emphasizes the microeconomic level as the appropriate one for State intervention. In particular, addressing market coordination problems that hamper innovation is crucial at late stages of development, when the economy already possesses a developed innovative potential. Economies at the technological frontier are usually endowed with necessary inputs, e.g. critical raw materials, as well as advanced technologies in intermediate and final productions. They are also endowed with highly qualified human capital and research centres able to undertake fundamental research, which provide an essential contribution for industrial innovation (Malerba, 2002). In this context, failures to innovate might derive from the lack of adequate demand (Geribadze, 1992) or from the lack of coordination in the production processes among production units, research centres and public bodies (Metcalfe, 1994). These problems of coordination, in turn, can be solved through State interventions that stimulate demand of high-tech goods, decrease private sector risk-aversion towards $R \& D$, provide a regulative framework and set up public agencies to incentivize and coordinate the efforts of innovative actors in the market and in the R\&D sector.

Recent developments in the evolutionary perspective provide alternative viewpoints on the approaches to innovation that can be pursued in late-stage economies. In particular, the emphasis seems to have shifted from allocation to structural change. More specifically, it has been argued that advanced economies need to trigger large-scale innovations in order to achieve extensive advantages vis-à-vis competitors, and that these innovations usually require technology-push approaches such as large-scale public investments in R\&D or in specific 
sectors (Janeway, 2012; Mazzucato, 2015). In this context, the potential misallocation of resources brought about by technology-push approaches (Freeman, 2001) is seen as an acceptable price to pay in order to achieve more ambitious objectives of innovation and economic growth.

In conclusion, the policies suggested by evolutionary theories tend to be relevant at late stages of development. Of central importance in this respect is the assumption of fundamental uncertainty, which is typical of economies at the technological frontier, as well as the emphasis on innovation, which is a key element for advanced economies to face competition in global markets. However, there is no consensus regarding the suitable policy approaches to adopt. In fact, whereas a strand of evolutionary economics tends to emphasize the role of (microeconomic) market-pull policy to minimise resource misallocation, another strand suggests the necessity to adopt technology-push approaches to achieve innovation at a large scale. The following analysis will show that both policy approaches can be reconciled in the practice of economic policy, as each pursues different policy objectives: whereas market-pull approaches are suitable to improve existing innovative potential, technology-push approaches are effective for creating new innovative potential. The practice of economic policy, and in particular the South Korean case, seem to support this argument.

\section{State intervention and economic policy: two post World War II experiences}

\subsection{The Italian approach to State intervention}

In the aftermath of World War II, the Italian economy was characterised by a backward industry and a dominant primary sector-typical aspects of early-stage economies. In this context, industrialisation was a priority for modernising the overall economy as well as for raising income levels. Nevertheless, the pursuit of a structural change was not only concerned with the increase of the secondary sector relative to the primary sector. Also within the manufacturing sector, the relative increase of capital-intensive sectors was seen as a driver for technical improvement and economic growth (Castellino, 1973; Costabile and Scazzieri, 2012; Cotula, 2000; Toniolo, 2013; Zamagni, 1993).

Sectoral policies played a central role for industrialisation. They succeeded to increase the productive capacity and technical capabilities of industrial sectors, contributing to the rise of total output. However, each sectoral target implied different policy purposes. Policies 
addressed to labour-intensive sectors, for instance agriculture and construction, had the function of decreasing unemployment and raising income levels in the short term. In contrast, public interventions on capital and technology-intensive sectors pursued industrial upgrade. They had the function of generating a process of catching-up with the most advanced economies at that time, namely the US, Germany, UK and France (Fuà and Sylos Labini, 1963; Hayward and Watson, 1975; VV AA, 1981a).

The strategy of industrial upgrade consisted in the expansion or ex-novo creation of sectors for the production of intermediate goods, as these are characterised by high technological content. These ranged from basic manufacturing (e.g. steel and chemical) to network industries (e.g. energy, transport and telecommunications) and other manufacturing (e.g. machine tools) (Petrilli, 1962). State-Owned Enterprises (SOEs) were the pillar of this strategy. The direct public intervention in these sectors was pivotal to overcome high risks and uncertainties connected to high capital and technology-intensive sectors (Lombardini, 1967; Rotondi and Quadrio Curzio, 2015; Toninelli, 2000). The creation of high-performing intermediate sectors was deemed strategic because of their systemic role. In fact, intermediate goods are critical inputs for a wide range of other intermediate and final productions (Cardinale, 2017; Furtado, 1964; Lowe, 1976). Technological improvements in these sectors generated several positive effects for the rest of the economy. For instance, they contributed to decrease the costs of production and increase the overall economic performance vis-à-vis international competitors (Crafts and Magnani, 2013; Cardinale, in press). They also contributed to a large-scale diffusion of technological spillovers in interdependent sectors (Antonelli et al., 2014).

The case of IRI, the largest Italian public holding, was emblematic of this strategy. IRI's role was carried out through share-controlling interests in a wide range of systemic sectors. The pursuit of technical improvement in key sectors was conducted through the import of advanced foreign technologies in an initial phase; in subsequent phases, the purpose was to leapfrog and generate new patents domestically. For instance, leapfrogs in the steel sector occurred thanks to IRI's purchase of the latest technology from the US. They contributed to decrease the cost and increase the quality of steel provisions for interdependent sectors (Ranieri, 2011; Russolillo, 2015; Saraceno, 1975). The rise of the Italian mechanics and naval sectors as global leaders in the subsequent years can be also explained as a result of the technical improvements in the steel sector. A strategic role was also played by ENI, the State 
monopolist in the oil \& gas sector. In this case, State ownership had the function to overcome obstacles of both economic and political nature. The lack of abundant energy resources in Italy implied that energy supplies were mostly imported. For this reason, a diplomatic effort was essential for ensuring abundant and affordable energy supplies. As in other capital-intensive sectors, State ownership played a key role also to ensure adequate levels of investments and overcome the poor performances of the private sector (Cardinale, 2017; Orsenigo et al., 1992; Zamagni, 1993).

The expansion of production was accompanied by a gradual process of trade liberalisation and incentives to exports. The increasing economic interdependence, especially with other European economies, proved beneficial to the Italian economy in different respects. For example, it made possible the exploitation of comparative advantages in labour-intensive productions, generating increasing surpluses from export (Castellino, 1973; Crafts and Magnani, 2013). Nevertheless, partial liberalisation had positive effects also for the nascent, less competitive capital and technology-intensive sectors. This occurred for different reasons. One is connected to the increasing demand for intermediate goods (inputs) brought about by the expansion of labour-intensive sectors. Another is related to their privileged access to growing national surpluses, brought about increasing exports. Ultimately, trade liberalisation eased the imports of foreign technologies, which were pivotal for their expansion and upgrade. Therefore, the partial liberalisation of foreign trade was not conceived only for allocative purposes, for instance to benefit from the increase in the scale of production of labour-intensive sectors. In contrast, this policy was functional to the pursuit of more ambitious objectives of industrial upgrade and structural change.

The achievement of major levels of industrialisation in the 1950s and 1960s marked the transition to an advanced stage of development in the 1970s. A structural change occurred as the contribution of industrial production to GDP increased remarkably, whereas traditional sectors such as agriculture were reshaped. Within the manufacturing sector, the share of capital and technology-intensive productions were substantially higher than before (Toniolo, 2013). However, the transition was not accompanied by the reshaping of State intervention, as it generally happens for mature economies. Two factors seemed to have contributed to the preservation of a wide range of States prerogatives. One was the rapidity of economic growth in the previous years, which had left development gaps across sectors and regions. The other was the unstable economic and political context that characterised the 1970s at the national and international level. 
As a consequence, the economic policy of the 1970s emphasized both macroeconomic and sectoral objectives. The stagflation deriving from the international oil shocks was tackled through expansive monetary and fiscal policy, which contributed to support aggregate demand (Giavazzi et al., 1989). The end of Bretton Woods agreements and the slowing down of international trade were additional external events that justified the adoption of an expansive policy. The benefits achieved in terms of economic growth and employment, however, were partially offset by increasing macroeconomic instability. The latter further increased in subsequent years following the "divorce" between the Treasury and the Central Bank. This measure entailed that the Central Bank was no longer committed to finance fiscal deficits, causing the increase of interest rates on public debt and its considerable growth in subsequent years (Epstein and Schor, 1986).

Economic policy in those years was also characterised by a strong emphasis on sectoral approaches. The establishments of heavy and chemical industry in the south of Italy aimed to fill the gap of development with the north (VV AA, 1981b), by increasing the share of capitalintensive productions also in the south of Italy. However, for domestic and international reasons, the vertically integrated large industry underwent a gradual decline (Colli, 2009). This was caused by external factors, for instance the decreasing levels of international demand of final goods and the increasing costs of key inputs (e.g. energy). But also to the lack of flexibility in the scale of production. Premature trade liberalization in the early stages of development and mismanagement might have also contributed to their weakness.

The crisis of the large industry did not prevent the rise of alternative models of industrial production, i.e. Industrial Districts (IDs) of Small and Medium Enterprises (SMEs) (Amin, 1989; Colli, 2009; Fortis and Quadrio Curzio, 2006). Among other factors, two structural conditions made possible for IDs' success in the 1970s. The increasing reduction of barriers to trade, which benefited their flexible supply chain and the fast adaptability to foreign demand (Cainelli and Zoboli, 2004). But also the supply of high quality inputs at a low price by the State-owned conglomerates. Both these advantages derived from the effects of current and past measures of economic policy. The former reflected the increasing trade liberalisation, although consistent sectors of the national economy were still protected by barriers to trade. The latter is the result of a constant effort to upgrade key sectors in the basic manufacturing and network industries. 
The consolidation of SMEs occurred during the 1980s and 1990s as liberalisation became the pillar of economic policy. SMEs' production model was suitable in a context of increasing trade liberalisation because of the unbundled supply chain. The latter provided much more flexibility in production and adaptability to changes in domestic and foreign demand as compared to the vertically integrated model. This was positive for allocative efficiency because it made possible the replacement of inefficient phases with imports. However, the loss of production in intermediate phases, characterised by high capital and technology intensity, had negative effects in terms of reduced innovative potential for the Italian economy (Siniscalco, 1988; Antonelli et al., 2014). Trade liberalisation was accompanied by restrictive policies to restore macroeconomic imbalances, generated by decades of high economic growth and stagflation in the 1970s. It is worth noting the process of industrial restructuring occurred between the late 1970s and early 1980s, which was implemented on a sectoral basis and consisted of mergers and privatizations of large industrial groups. The goal was to restore productive and market efficiency by rationalising production and decreasing corporate debt (Acquaviva, 2005).

The allocative approach assumed increasing importance with the intensification of European institutional integration and the creation of the European Single Market. The Single European Act in 1986 and the Maastricht Treaty in 1992 represented important steps in this direction. Liberalisation of movement of goods, services, capital and workers were conceived to increase market efficiency, whilst restrictive budgetary and monetary policy to restore efficiency at the macroeconomic level (Dinan, 2005). The extensive privatisation of public industry was functional to the logic of market liberalisation, although implemented on a sectoral basis as most firms were former monopolists. The decreased level of political control of large market shares was conceived to create the conditions for a more equal competition among private competitors. Nevertheless, privatisation occurred only partially, with most of key sectors being still under State control, e.g. high-tech, defence, energy, ICT and transport (Cardinale, 2017; Florio, 2013; Toninelli, 2000). European integration and partial privatisation laid the foundations for the current approach to economic policy, which envisages the adoption of both microeconomic (market-pull) and sectoral (technology-push) approaches to policy for the pursuit of both market competition and innovation.

The main obstacles to market-led innovations are related to high uncertainty in the development of cutting edge technologies, lack of funding and facilitated access to credit for SMEs, lack of platforms that maximise synergies between State agencies, universities, 
scientific laboratories and businesses. These obstacles have been widely addressed in the Italian innovation policy at both the national and European levels of governance (Pianta, 2014). At the national level, "Innovation, Growth and Employment Plan" aims to promote market-led innovations through incentives to $R \& D$ and the development of physical, social and research infrastructure projects (Coletti, 2007). At the European level, "Horizon 2020" provides the main framework on which research and innovation is funded. It pursues several objectives, ranging from developing new industrial technologies (including in SMEs) to facing societal challenges in the fields of health, energy and transport (European Commission, 2017).

Sectoral interventions are mainly carried out through major State shares in cutting-edge and systemic industries. The State control of strategic companies aims to promote their growth and avoid underinvestment. The latter is likely to occur because of private sector aversion to risk and inclination to short-term profitability. However, in the Italian case, State ownership does not seem to incentivize large-scale innovations. This emerges from the extensive adoption of the model of mixed ownership on which public and private shareholders coexist. The presence of private shareholders entails that innovation must be reconciled with short-term profitability, leaving little room for large-scale innovation (Cardinale, 2017; Cardinale, in press; see also Lucchese et al., 2016 on the role of Cassa Depositi e Prestiti).

In conclusion, the prevalence of microeconomic (market pull) approaches and the transition to mixed ownership reflect the transition to a late stage of economic development. Both approaches reflect the need to incentivize economic growth and innovation on a smaller scale. This is explainable by the lower margins of technical improvement and the lower levels of socially desirable investment required, but also by the proximity to the technological frontier and the high uncertainty connected to it. Nevertheless, the presence of major State shares in strategic industries reflects the systemic relevance of certain sectors also in late stages of development and the necessity to manage them differently from other sectors.

\subsection{The South Korean approach to State intervention}

The South Korean approach to State intervention shows several similarities with the Italian approach in all phases of economic development since the end of World War II, although the South Korean economy was relatively less developed than the Italian economy, as shown by several economic indicators. For example, average income during the 1950 s was $\$ 876$ in South 
Korea and $\$ 3425$ in Italy. The share of agriculture to GDP was respectively $44 \%$ and $25 \%$, showing substantial differences in their previous paths to industrialisation. In fact, whereas South Korea started industrialising only by 1910, in occasion of the Japanese colonisation, Italian industry has its roots in the first half of the $19^{\text {th }}$ century. Moreover, South Korea's disadvantage was further aggravated by the extent of war time destruction, which amounted to $86 \%$ of the GNP in 1953 (Lee, 2001), whereas Italy's damage amounted only to 8\% of the capital value of 1938 (Zamagni, 1990). Despite these gaps in development, both countries shared the need to pursue sustained structural change and a high rate of growth to upgrade their economies and catch-up with more advanced countries.

In the aftermath of the South Korean war, industrialisation was considered the only way to upgrade the economy, tackle extreme poverty, and raise the low income levels. This explains the emphasis on the import substitution industrialization (ISI) strategy since the early phases. It consisted of quantitative restrictions and high tariffs on imports, and had the function of protecting the nascent industry from foreign competition (Kim, 1974). Despite the initial efforts, the annual average of economic growth in the 1950s did not exceeded 3,8\%, a relative low rate considering the high margins of catching up (Cole and Lyman, 1971). This trend changed in the 1960s with General Park Chung-hee's takeover. The new administration successfully accomplished an ambitious project of industrialisation through a series of fiveyears economic development plans. In this context, the partnership between the State and the private sector was decisive to trigger industrialisation. Another element of success was the introduction of institutional innovations such as the establishment of the Economic Planning Board (EPB). The latter contributed to assign primary importance to economic development over other issues in the political agenda (Haggard et al., 1991).

The priority of the First Five-Year Economic Development Plan (1962-1966) was to protect the nascent capital-intensive industry through import duties, and to support the labour-intensive industry with export subsidies (Hong, 1979; Kim, 1974). The exploitation of labour-intensive industry's comparative advantage made it possible to remarkably increase surpluses from exports. These were functional for financing the ISI, namely the expansion and upgrade of the capital-intensive industry. The import of foreign technology was another essential element contributing to industrial upgrade (Dornbusch and Park, 1987). The State ownership in the financial sector facilitated the process of capital allocation towards the policy targets. The First Five-Years Economic Development Plan succeeded in the pursuit of the main targets, as the economy grew by $8.9 \%$ yearly, drawn by the growth of exports of $29.2 \%$ yearly (Kim, 1997). 
Sectoral planning emerged as a key element of economic policy in occasion of the Second Five-Year Economic Development Plan (1967-1971). The plan aimed to promote structural change from labour-intensive to capital-intensive sectors. In particular, this was done by incentivizing the growth of heavy and chemical industries. The main sectors targeted were iron and steel, machinery, petrochemical, electronics and shipbuilding (Sakong and Koh, 2010). The role of South Korean Chaebols was crucial in the implementation of the Heavy and Chemical Industrialisation (HCI). The Chaebols are South Korean multi-industry business conglomerates usually owned by a single family. The trust relations with the political elites and their ability to carry out large-scale industrial and infrastructure projects made them the ideal partners for the implementation of industrial policy. Outsourcing to Chaebols made it possible to avoid relying on foreign companies and to pursue economic and political autonomy from foreign powers (Jones and Sakong, 1980; Kim, 1997). The State succeeded to involve Chaebols in the implementation of industrial policy through incentives of financial nature, for instance fiscal incentives and facilitated access to credit. Nevertheless, incentives were also allocated on the basis of firms' performances, e.g. their exports. This measure shows that firm performance was a fundamental element to pursue in addition to the sectoral targets. Overall, South Korean economic policy proved to be successful in those years, as witnessed by the average annual growth of about $10 \%$.

The Third Five-Year Economic Development Plan (1972-1976) was conceived to intensify and accomplish the HCI previously undertaken. The plan aimed at further increasing the share of capital-intensive sectors at the expense of labour-intensive sectors in their contribution to GDP. Seven industries were targeted to lead the economy towards this structural change: steel, machinery, nonferrous metal, chemical engineering, electronics and shipbuilding (Galbraight and Kim, 1998). Some of these sectors, e.g. network industries, steel and chemical, were dominated by SOEs. The State ownership of certain strategic industries had two main interconnected purposes, namely to cope with high upfront costs and to be able to influence directly and effectively sectors at the heart of economic development (Nam, 2004). Ultimately, both the strategies of State-Chaebols partnership and State ownership of strategic industries were conceived for a common goal: to trigger a structural change that would lead to comparative advantages in high added-value sectors.

Overall, in the period between early 1960s and late 1970s, South Korean economic policy succeeded in the pursuit of most of the long-term objectives, thanks to the State-led sectoral planning (Heo, 2001; Luedde-Neurath, 1988; Stern, 1995). Economic growth was high and persistent, triggered by export-led industrialisation. The share of manufacturing increased from 
$12 \%$ to $27 \%$, whereas the share of agriculture decreased from $43.1 \%$ to $12.4 \%$. The share of capital-intensive industry increased from $20.9 \%$ to $64 \%$, at the expense of labour-intensive industry, which decreased from $79.1 \%$ to $36 \%$ (Kim, 1997). Leapfrogs occurred in several capital-intensive sectors, for instance steel, car industry and shipbuilding (Kim, 1993; Sohn et al., 2009). These records brought South Korea to compete in international markets with the most advanced economies. This suggests that by the early 1980s, the developing phase was accomplished and a transition to an intermediate stage of development had occurred.

The transition to a mature economy induced consistent changes also in the approaches to economic policy. The reduced margins of growth as well as the acquired comparative advantages in high added-value productions called for the adoption of allocative approaches.

At the microeconomic level, trade liberalization and privatisation of State-owned enterprises were key changes of economic policy. They were conceived to benefit from the recently achieved comparative advantages in high value-added sectors. Trade liberalisation was pursued through the subscription of GATT agreements, which had the effect of decreasing the average level of tariffs from $34.4 \%$ to $9.8 \%$ and quantitative restrictions by more than $30 \%$ (Kim, 1997). The rationale for privatisation laid mostly on the maturity of the economy, which entailed the private sector's ability to provide the socially desirable levels of investment ${ }^{4}$. Privatisation was thought to be beneficial also for competition and efficiency, as the decrease of direct political influence would have reduced market distortions. This idea gained major support during and after the 1997 financial crisis. In this circumstance, the extensive State intervention in the economy was considered pivotal for excessive corporate debt accumulation and a main cause of the financial crisis (Sakong and Koh, 2010). Nevertheless, opposite views identify the sudden liberalisation of the 1980s as the main driver for growing financial imbalances and the 1997 crash, and see privatisation as an occasion for domestic and foreign speculation (Chang et al., 1998; Crotty and Lee, 2004; Mc Kay, 2003).

The transition to an intermediate stage of development and the emphasis on allocative approaches of economic policy did not entail the demise of traditional sectoral approaches. In this phase, sectoral policies had mixed purposes: those of developmental nature were conceived to fill the technological gaps in high-tech sectors, whereas those of allocative nature were

\footnotetext{
${ }^{4}$ Note that privatisation of SOEs in the 1980s and 1990s was pursued extensively worldwide. Therefore, international factors may have also played a role, in addition to domestic reasons discussed here.
} 
thought for industrial rationalisation and were addressed mostly towards the recently developed capital-intensive sectors.

For instance, the development of telephone control units and Code Division Multiple Access (CDMA) technology (Han, 2007), as well as the Korean Information Infrastructure (KII) project (Lee, 2009; Shin, 2007) are typical examples of technology-push interventions. They were planned and executed for the purpose of leapfrogging in Information and Communication Technology (ICT), a sector of strategic relevance and at the technological frontier.

In contrast, the industrial rationalization carried out in sectors such as automotive was adopted for allocative purposes. The aim was to tackle production and market distortions caused by decades of uneven development and extensive public incentives. This policy envisioned mostly mergers of firms, but also regulation of market entry and the restructuring of corporate debt. In particular, mergers and regulation of market entry aimed at reducing overproduction in overcrowded sectors and strengthening the existing firms, improving productive efficiency (Kim, 1997).

The transition to a late stage of development occurred between the 1990s and 2000s, as the South Korean economy approached the technological frontier in various high-tech sectors. It succeeded to developed leaderships in semiconductors, energy storage, renewables and smart grids, medical devices and fuel cells among others (Kim, 1993). In this phase of development, microeconomic approaches dominated almost every aspect of economic policy. This was evident in the liberalization of foreign trade and domestic markets, but also in the introduction of new approaches to innovation policy. Innovation became one of the priority of economic policy as it plays a decisive role in maintaining and further improving economic performances vis-à-vis other advanced economies.

In this stage of development, South Korean innovation policy is characterised by a mix in the approaches adopted. The policy envisages the coexistence of market-pull (microeconomic) and technology-push (sectoral) approaches. The mix is probably explainable by the need to compensate benefits (low-risk innovation) and drawbacks (small-scale innovation) of microeconomic approaches, with benefits (large-scale innovation) and drawbacks (potential large-scale failures) of sectoral approaches. The National Strategy for Green Growth 20092050, a State multi-year strategy for the development of high-tech green technologies, is an example on how mixed approaches to innovation can coexist. In this case, sectoral planning 
aims to develop green technologies on a large scale, whereas the emission trading system aims to incentivize a market-led transition to a low-carbon economy (Mathews, 2012).

Other plans are mainly devoted to technology-push approaches. For instance, the National Strategy Project, a multibillion innovation-oriented State plan, is dedicated to develop sectors with the highest technological content, considered as the new growth engine for the South Korean economy. The sectors range from artificial intelligence to virtual reality, autonomous vehicles, light-weight materials and smart cities. In contrast, microeconomic interventions are generally addressed to market failures hampering innovation. In particular, those caused by the risks inherent in high-tech are addressed by State expenditure in $R \& D$, whereas those deriving from lack of coordination among innovative actors (public bodies, industry and research centres) — which is a key requirement for sustained innovation at late stage of developmentare usually addressed in the context of the Korean National Innovation System regulation (Lee and Park, 2006).

\section{Discussion and concluding remarks}

The Italian and South Korean approaches to State intervention have shown several similarities at each stage of development, despite differences in key economic and political factors. The differences especially concerned the initial level of industrialisation, the relations between economic and political elites, and the degree of political stability. For example, although Italy's process of industrialisation was in a more advanced stage, which usually entails a greater role of the private sector, the Italian industrial policy was centred on SOEs. This was necessary to overcome structural weaknesses of the private sector, such as smallscale production, in order to be able to compete globally with the most advanced economies. In addition, the reliance on SOEs can be explained by the inheritance of an extensive system of public holdings from previous administrations, and the opportunity to reorganise it and reorient its policy strategies rather than dismantle it and face the uncertainties posed by a new model of industrial development. The reliance on Chaebols in South Korea can be also explained by a choice of continuity with the past, namely the opportunity to rely on existing private corporations, inherited from the Japanese colonisation. However, the importance of Chaebols did not prevent the South Korean State to establish SOEs in sectors of strategic importance (e.g. network industries). Ultimately, the different performance of the two economies largely depended on political governance. Italy suffered from political instability 
generated by unsolved domestic disputes among the main political forces and by its geopolitical relevance in the Cold War. Political instability entailed the need to face continuous challenges in the short-term, negatively affecting the success of economic planning. The mixed results obtained from the macroeconomic and industrial policies undermined to a certain extent the long-term growth and innovative potential of the Italian economy. In contrast, the strong State-Chaebols cooperation and the relative political stability of South Korea made it possible to accomplish most long-term economic objectives.

Despite differences in the paths to industrial development and economic performances, similarities in the approaches to State intervention prevailed. These were evident at all stages and reflect the common nature of the economic challenges posed by each stage of development. In fact, whereas in early stages sectoral policies prevailed, in advanced stages microeconomic policies were prominent. The rationale for this trend can be explained by the priorities that characterise each stage and the suitability of each approach for their pursuit.

In early stages, sectoral policies were pivotal for industrial upgrade and economic growth. The creation of new comparative advantages in high value-added sectors (i.e. basic manufacturing, network industries) was necessary for the pursuit of these policy objectives ${ }^{5}$. In this context, the dynamics of production were more important than market dynamics, as important segments of the productive system, particularly intermediate sectors, were underdeveloped. Their systemic influence, which derives from their nature of inputs, has great implications for the pursuit of high and balanced economic growth, as well as technological catching-up ${ }^{6}$. Despite the forms of interventions were slightly different in the Italian and South Korean cases, the rationale was the same. In fact, both State-Owned Enterprises in Italy and State-Chaebols partnerships in South Korea dominated the intermediate sectors.

It has been shown that structural dynamics theories provide a suitable lens to understand the relevance of sectoral policies in early stages. In fact, sectoral analysis makes it possible to differentiate the systemic relevance of sectors, and to envisage how the relative expansion of

\footnotetext{
${ }^{5}$ See Peneder (2003), Saviotti and Pyka (2004), on the positive correlation between qualitative structural changes (relative increase of high-added value sectors), economic growth and employment. See also FosterMcGregor and Vespagen (2000) on the importance of structural change for the transition from early to intermediate stages of development in Asian economies. Note the divergent view of Timmer and Tsirmai (2000), who argue that the importance of structural change for productivity and economic growth has been overstated at the expense of technical improvements occurring economy-wide.

${ }^{6}$ Note that also other conditions are needed for catching-up successfully. According to Verspagen (1991), these are a relative low technological gap between the leader and the follower, and the capability to assimilate foreign technology in the national economy.
} 
certain sectors brings to specific structural changes entailing the creation of new comparative advantages in high value-added sectors.

A transition to an intermediate stage occurred in the 1980s when major objectives of growth and upgrade were accomplished and intermediate sectors (infrastructure, network industries, basic manufacturing) became competitive and able to serve the final sectors. Their adequate development made it possible for policy-makers to emphasize final phases of production and market exchanges. This entailed a reshaping of policy priorities from structural change to allocative efficiency, inducing the emergence of microeconomic policies as the dominant approach at the expense of sectoral policies ${ }^{7}$. Allocative efficiency was pursued at the microeconomic (market) level through liberalisation of domestic markets and foreign trade and at the macroeconomic level through restrictive monetary and fiscal policies. The former made it possible to exploit the recently achieved comparative advantages in high value-added sectors. The latter aimed to restore macroeconomic imbalances caused by decades of high rates of economic growth.

It has been shown that allocative theories provide a lens to interpret the prevalence of microeconomic approaches to policy in intermediate and late stages. Microeconomic policies, in fact, are effective for the pursuit of allocative objectives, which become a priority in advanced stages, when major structural changes have already occurred. In fact, whereas liberalisation is justified by reduced margins of economic growth domestically, it is also pivotal to increase the scale of production of high added-value sectors thanks to foreign trade.

As the Italian and South Korean economies approached the technological frontier in certain sectors between the 1990s and 2010s, microeconomic approaches prevailed along with technology-push (sectoral) approaches to innovation policy. The prevalence of microeconomic approaches has two main explanations. One has to do with the need to support the innovative potential of technologically advanced economies, which generally requires State intervention to remove obstacles to innovation (e.g. coordination among innovative actors, SMEs' riskaversion and difficult access to credit). Another is connected to the fundamental uncertainty

\footnotetext{
${ }^{7}$ Although the Italian economy reached its key development objectives no later than the late 1960s-early 1970s, external events in the 1970s (oil shocks and domestic political instability) made it impossible for allocative approaches to prevail. In fact, sectoral and macroeconomic interventions still continued to dominate economic policy to counteract economic fluctuations. In contrast, the South Korean economy marked its transition to an intermediate stage — and hence to allocative approaches — by the late 1970s-early 1980s, once the HCI was accomplished.
} 
that characterises the technological frontier ${ }^{8}$, and the need to minimise resource misallocation by avoiding high risks in the development and marketability of new technology.

The paper has shown that evolutionary theories provides a lens to interpret innovation policy at late stages. In fact, they focus on strategies to support innovation taking into account the fundamental uncertainty that is typical of economies at the technological frontier.

Even if sectoral and microeconomic approaches have prevailed in early and more advanced stages of development respectively, economic policy has been always characterised by their simultaneous adoption, although to different extents. The need to reconcile sectoral and microeconomic approaches emerges from this paper as a constant element that characterises each stage of economic development. This shows the complementary character of the structural and allocative approaches in the practice of economic policy. The paper suggests that the adoption of multiple policy approaches reflects the uneven development and specificities of different sectors in a given economy.

In early stages, policies of allocative nature were essential for the success of State-led sectoral plans of industrial upgrade. In fact, partial liberalisation of foreign trade maximised the exploitation of existing comparative advantages in labour-intensive sectors, increasing capital accumulation. The latter made possible for large-scale sectoral investments in high value-added productions and the subsequent creation of new comparative advantages. Differentiated policy approaches, therefore, were conceived to suit the uneven levels of sectoral development, namely low and high value-added sectors.

At intermediate stages, sectoral policies were adopted along with large-scale liberalisations ${ }^{9}$. Nevertheless, in this phase sectoral interventions had mixed purposes, which reflected a higher level of maturity of the economic system. Whereas policies of developmental nature were conceived to fill the technological gaps in high-tech sectors, policies of allocative nature were adopted to pursue industrial rationalisation. The former reflected the persistence of uneven levels of sectoral development and were incentivized by the specificity of high-tech sectors. The latter indicated an overall economic maturity, brought about by high rates of industrial development in previous years and overproduction in certain sectors, and the need to emphasize objectives of allocative rather than development nature.

\footnotetext{
${ }^{8}$ See Song et al. (2007) on how fundamental uncertainty affects the outcome of R\&D frontier projects in South Korea.

${ }^{9}$ See Sapelli (1994) on the importance of both foreign trade and State-led technology-push for innovation in strategic industries.
} 
At the technological frontier, technology-push approaches are implemented in the comprehensive framework of market-pull approaches. This mix makes it possible to compensate benefits (large-scale innovation) and drawbacks (potential large-scale failures) of sectoral approaches, with benefits (low-risk innovation) and drawbacks (small-scale innovation) of microeconomic approaches. This mix reflects the sectoral specificity of hightech sectors and their systemic importance also in late stages of development ${ }^{10}$.

The foregoing analysis shows the need for different approaches of economic policy to coexist at different stages of development. It also highlights the different implications of each policy approach at each stage of development. Whereas sectoral approaches are adopted mainly for industrialisation purposes in early stages, they pursue also efficiency and innovation objectives in more advanced stages. In contrast, microeconomic approaches are adopted mainly to generate surpluses from low value-added sectors in early stages, and to pursue allocative efficiency and exploit comparative advantages in high added-value sectors in more advanced stages.

This suggests that the adoption of a policy mix does not only respond to the policy-makers' need to face lobbying pressure from particular interests. The need to balance winners and losers, or even to create synergies among them, may reflect an attempt to preserve the longterm competitiveness of the economic system. In contrast, the failure to harmonise such interests may affect the system's resilience and hinder long-term economic development. This was the case for many Latin American economies. In fact, as Mamalakis (1969) pointed out, the failure of economic planning was mainly caused by policy-led imbalances between emerging (e.g. heavy industries) and declining (e.g. agriculture) sectors. In other words, drawing too many resources from declining sectors to support emerging sectors generated deficits in the former that ultimately prevented the long-term development of the latter, which hampered overall economic performance.

The different implications that each policy approach has at each stage of development suggest that no single theoretical perspective — structural, allocative, evolutionary — can on its own capture the multifaceted nature of economic policy. For instance, allocative theories alone do not provide a suitable lens to understand how early-stage economies could defy comparative

\footnotetext{
${ }^{10}$ The systemic importance of high-tech sectors emerges, for example, from the contribution of Ten Raa and Wolff (2000), who analyze the contemporary US economy and show that high-tech sectors are the engines of economic growth because of their high potential to transmit technological spillovers to the rest of the economy.
} 
advantages in labour-intensive sectors; they are also unable to explain that allocative efficiency may be pursued not only through microeconomic policies, but also through sectoral interventions. Similarly, the strand of evolutionary theory that focuses on incremental innovation does not capture the reasons why innovation at the technological frontier might benefit from large-scale technology-push interventions. This makes it difficult for allocative and evolutionary theories to conceive of sectoral interventions for both development and allocative purposes. 


\section{References}

Acquaviva, G., 2005. La politica economica italiana negli anni ottanta 1. ed., Venezia: Marsilio.

Amable, B., 2000. International specialisation and growth. Structural Change and Economic Dynamics, 11(4), pp.413-431.

Amin, A., 1989. Flexible specialisation and small firms in Italy: myths and realities. Antipode, 21(1), pp.13-34.

Antonelli, C., Barbiellini Amidei, F. \& Fassio, C., 2015. The mechanisms of knowledge governance: State owned enterprises and Italian economic growth, 1950-1994. Structural Change and Economic Dynamics, 32, pp.43-63.

Araujo, R.A. \& Teixeira, J.R., 2002. Structural change and decisions on investment allocation. Structural Change and Economic Dynamics, 13(2), pp.249-258.

Arrow, K. \& Hahn, F.H., 1983. General Competitive Analysis, Amsterdam: North-Holland.

Arrow, K.J., 1969. The organization of economic activity: issues pertinent to the choice of market versus nonmarket allocation. The analysis and evaluation of public expenditure: the PPB system, 1, pp.59-73.

Baldwin, R.E., 1969. The Case Against Infant-Industry Tariff Protection. Journal of Political Economy, 77(3), pp.295-305.

Baranzini, M. \& Scazzieri, R., 1990. The economic theory of structure and change, Cambridge: Cambridge University Press.

Cainelli, G. \& Zoboli, R., 2004. The Evolution of Industrial Districts: Changing Governance, Innovation and Internationalisation of Local Capitalism in Italy, Heidelberg; New York: Physica-Verlag.

Cardinale, R., 2017. The European gas sector: political-economy implications of the transition from state-owned to mixed-owned enterprises. In The Reform of Network Industries: 
Evaluating Privatisation, Regulation and Liberalisation in the EU. Edward Elgar Publishing.

Cardinale, R. Changing strategies in new contexts: The governance of European State-Owned Enterprises in the $21^{\text {st }}$ century. In Bance, P., Bernier, L., Florio, M., "State Owned Enterprises in the $21^{\text {st }}$ century: A new Handbook", CIRIEC, in press.

Castellino, O., 1973. La politica economica italiana dal 1946 al 1970. Torino: Giappichelli.

Chang, H.-J., 1994. The political economy of industrial policy. Basingstoke; New York: Macmillan; St.Martin's.

Chang, H.J., Park, H.H. \& Yoo, C.G., 1998. Interpreting the Korean crisis: Financial liberalization, industrial policy and corporate governance. Cambridge Journal of Economics, 22(6), pp.735-746.

Chiaromonte, F. \& Dosi, G., 1993. Heterogeneity competition and macroeconomic dynamics. Structural Change and Economic Dynamics, 4(1), pp.39-63.

Coase, R.H., 1960. The Problem of Social Cost, The Journal of Law \& Economics, 3, pp.1-44.

Cole, D. \& Lyman, P., 1971. Korean Development, Cambridge, Mass.: Harvard University Press.

Coletti, R., 2007. Italy and innovation: Organisational structure and public policies, Rome: CeSPI.

Colli, A., 2009. Industrial districts and large firms: The stubborn persistence of a weak productive model. In G. Becattini, M. Bellandi, \& L. De Propis, eds. A Handbook of Industrial Districts. Cheltenham: Edward Elgar Publishing.

Costabile, L. \& Scazzieri, R., 2012. Tendenze recenti del pensiero economico italiano. Treccani. Available at: http://www.treccani.it/enciclopedia/tendenze-recenti-delpensiero-economico-italiano \%28Il-Contributo-italiano-alla-storia-del-Pensiero:-

\section{Economia\%29/}

Cotula, F., 2000. Stabilità e sviluppo negli anni Cinquanta, Roma: Laterza. 
Crafts, N. \& Magnani, M., 2013. The golden age and the second globalization in Italy. In G. Toniolo, ed. The Oxford Handbook of the Italian Economy Since Unification. New York: Oxford University Press.

Crotty, J. \& Lee, K.K., 2004. Was the IMF's Imposition of Economic Regime Change in Korea Justified? A Critique of the IMF's economic and Political role before and after the crisis, 77. Working Paper Series. Political Economy Research Institute, University of Massachussets, Amherst.

Dasgupta, A.K., 1987. Epochs of economic theory, Oxford; New York: B. Blackwell.

Debreu, G., 1959. Theory of Value. An Axiomatic analysis of Economic Value, New York: Wiley.

Dinan, D., 2005. Ever closer union: An introduction to European integration, Boulder, CO: Lynne Rienner Publishers.

Dobb, M., 1960. An Essay on Economic Growth and Planning, London: Routledge \& Kegan Paul.

Dornbusch, R. \& Park, C.Y., 1987. Korea Growth Policy. Brookings Institutions Press, 2, pp.389-454.

European Commission, E., 2017. Horizon 2020. The EU Framework Programme for Research and Innovation. Available at: https://ec.europa.eu/programmes/horizon2020/ [Accessed September 14, 2017].

Epstein, G., \& Schor, J., 1986. The divorce of the Banca d'Italia and the Italian Treasury: a case study of central bank independence. Discussion paper series, 1269, Harvard Institute of Economic Research: Cambridge Mass.

Fagerberg, J., 2000. Technological progress, structural change and productivity growth: a comparative study. Structural Change and Economic Dynamics, 11(4), pp.393-411.

Florio, M., 2013. Network industries and social welfare: The experiment that reshuffled European utilities, Oxford: Oxford University Press. 
Fortis, M., Quadrio Curzio, A., 2006. Industria e distretti. Un Paradigma di perdurante competitività Italiana, Bologna: Il Mulino.

Foster, J., 1997. The analytical foundations of evolutionary economics: from biological analogy to economic self-organization. Structural Change and Economic Dynamics, 8(4), pp.427-451.

Foster-McGregor, Neil Verspagen, B., 2016. The Role of Structural Change in the Economic Development of Asian Economies. Asian Development Review, 33(2), pp.74-93.

Freeman, C., 2001. A hard landing for the "New Economy"? Information technology and the United States national system of innovation. Structural Change and Economic Dynamics, 12(2), pp.115-139.

Fuà, G. \& Sylos Labini, P., 1963. Idee per la programmazione economica, Bari: Laterza.

Furtado, C., 1964. Development and underdevelopment, Berkeley: University of California Press.

Galbraith, J.K. \& Kim, J., 1998. The legacy of the HCI: An empirical analysis of Korean industrial policy. Journal of Economic development, 23(1), pp.1-20.

Geribadze, A., 1992. The implementation of industrial policy in an evolutionary perspective. In U. Witt, ed. Explaining Process and Change: Approaches to Evolutionary Economics. University of Michigan Press.

Giavazzi, F., Spaventa, L. \& Masera, R., 1989. Italy: The Real Effects of Inflation and Disinflation. Economic Policy, 4(8), pp.133-171.

Haggard, S., Kim, B. \& Moon, C., 1991. The Transition to Export-led Growth in South Korea: 1954-1966. The Journal of Asian Studies, 50(4), pp.850-873.

Han, I.-S., 2007. Success of CDMA Telecommunications Technology in Korea: The Role of the Mobile Triangle. In Innovation and Technology in Korea: Challenges of a Newly Advanced Economy. New York: Springer Science \& Business Media. 
Hayward, J. \& Watson, M., 1975. Planning, politics and public policy: The British, French and Italian experience, Cambridge: Cambridge University Press.

Heckscher, G., Flam, H., Ohlin, B., Flammer, J., 1991. Heckscher-Ohlin trade theory, Cambridge, Mass.: MIT Press.

Heo, Y., 2001. Development strategy in Korea reexamined: an interventionist perspective. Social Science Journal, 38(2), pp.217-231.

Hong, W., 1979. Trade, distortions, and employment growth in Korea, Seoul: Korean Development Institute.

Janeway, W., 2012. Doing Capitalism in the Innovation Economy: Markets, Speculation and the State, New York: Cambridge University Press.

Jones, L.P. \& SaKong, I., 1980. Government, business, and entrepreneurship in economic development: The Korean case, Cambridge, Mass.: Harvard University Press.

Kim, E.M., 1997. Big business, strong state: collusion and conflict in South Korean developments, 1960 - 1990, Albany: State University of New York Press.

Kim, K.S., 1974. Outward-looking industrialization strategy: The case of Korea, Seoul: Korea Development Institute.

Kim, L., 1993. National System of Industrial Innovation: Dynamics of Capability Building in Korea. In R. R. Nelson, ed. National innovation systems: A comparative analysis. Oxford: Oxford University Press, pp. 357-383.

Krugman, P., 1981. Intraindustry specialization and the gains from trade. Journal of political Economy, 89(5), pp.959-973.

Lee, J.W., 2001. The Impact of the Korean war on the Korean economy. International Journal of Korean Studies 5(1), pp. 97-118.

Lee, J. \& Park, C., 2006. Research and development linkages in a national innovation system: Factors affecting success and failure in Korea. Technovation, 26(9), pp.1045-1054. 
Lee, K.-S., 2009. A final flowering of the developmental state: the IT policy experiment of the Korean Information Infrastructure, 1995-2005. Government Information Quarterly, 26, pp.567-576.

Leontief, W., 1991. The economy as a circular flow. Structural Change and Economic Dynamics, 2(1), pp.181-212.

Lewis, A., 1954. Economic development with unlimited supplies of labor. The Manchester School, 22(2), pp.139-191.

Lin, J.Y., 2009. Economic Development and Transition: Thought, Strategy and Viability, Cambridge: Cambridge University Press.

Lipsey, R.G. \& Fraser, S., 1998. Technology policies in neo-classical and structuralistevolutionary models. STI Review, 1998 (1: Special Issue on New Rationale and Approaches in Technology and Innovation Policy), pp.31-73.

List, F., 1885. The National System of Political Economy, London: Longmans, Green.

Lombardini, S., 1967. La programmazione: Idee, esperienze, problemi, Torino: Einaudi.

Löwe, A., 1976. The Path of Economic Growth, Cambridge: Cambridge University Press.

Lucchese, M., Nascia, L. \& Pianta, M., 2016. Industrial policy and technology in Italy. Economia e Politica Industriale, 43(3), pp.233-260.

Luedde-Neurath, R., 1988. State Intervention and Export-Oriented Development in Korea. In G. White \& J. Gray, eds. Developmental states in East Asia. New York: St. Martin's Press.

Malerba, F., 2002. Sectoral systems of innovation and production. Research Policy, 31(2), pp.247-264.

Mamalakis, M., 1992. Sectoral Conflicts in the U.S. and the Soviet Union: A Mesoeconomic Analysis. Eastern Economic Journal, 18(4), pp.421-428.

Mamalakis, M., 1969. The Theory of Sectoral Clashes. Latin American Research Review, 4(3), pp.9-46. 
Mathews, J.A., 2012. Green growth strategies-Korean initiatives. Futures, 44(8), pp.761769.

Mazzucato, M., 2015. The entrepreneurial state: Debunking public vs. private sector myths, London; New York: Anthem Press.

Mc Kay, J., 2003. The restructuring of the Korean economy since 1986 and the onset of the financial crisis: the industrial financial nexus. In M. Tcha \& C.-S. Suh, eds. The Korean economy at the crossroads. London: Routledge Curzon, pp. 69-83.

Metcalfe, S., 1994. Evolutionary Economics and Technology Policy. The Economic Journal, 104(425), pp.931-944.

Moreau, F., 2004. The role of the state in evolutionary economics. Cambridge Journal of Economics, 28(6), pp.847-874.

Nam, I.C., 2004. Recent Developments in the Public Enterprise Sector of Korea. In Governan Regulation, and Privatization in the Asia-Pacific Region. Chicago: University of Chicago Press.

Naqvi, K., 1963. Machine tools and machines: a physical interpretation of the marginal rate of saving. Indian Economic Review, 6(3), pp.19-28.

Nelson, R.R. \& Winter, S.G., 1982. An evolutionary theory of economic change, Cambridge, Mass.; London: Belknap Press.

Nightingale, J. \& Laurent, J. eds., 2001. Darwinism and evolutionary economics, Cheltenham: Edward Elgar.

Nurkse, R., 1953. Problems of Capital Formation in Underdeveloped Countries, Oxford: Basil Blakwell.

Orsenigo, L., Sapelli, G. \& Toninelli, P.A., 1992. The Evolution of the Strategy and Structure of a State-Owned Company: The Case of Agip Petroli S.p.A., 1960-1990. Business and Economic History, 21(2), pp.129-137. 
Pasinetti, L.L., 1981. Structural Change and Economic Growth. A Theoretical Essay on the Dynamics of the Wealth of Nations, Cambridge: Cambridge University Press.

Pasinetti, L.L., 1993. Structural Economic Dynamics: A Theory of the Economic Consequences of Human Learning, Cambridge: Cambridge University Press.

Peneder, M., 2003. Industrial structure and aggregate growth. Structural Change and Economic Dynamics, 14(4), pp.427-448.

Petrilli, G., 1962. The Institute for industrial reconstruction. Annals of Public and Cooperative Economics, 33(1-2), pp.15-19.

Pianta, M., 2014. An industrial policy for Europe. Seoul Journal of Economics 27(3), pp.277305.

Pigou, A.C., 1920. The economics of welfare., London: Macmillan.

Prebisch, R., 1950. The Economic Development of Latin America and its Principal Problems, New York: United Nations, Department of Economic Affairs.

Quadrio Curzio, A., 1986. Technological Scarcity: An Essay on Production and Structural Change. In M. Baranzini \& R. Scazzieri, eds. Foundations of Economics. Structures of Inquiry and Economic Knowledge. Oxford and New York: Basil Blackwell, pp. 331-338.

Quadrio-Curzio, A. \& Pellizzari, F., 1999. Rent, resources, technologies, Berlin; London: Springer.

Raa, T. \& Wolff, E.N., 2000. Engines of growth in the US economy. Structural Change and Economic Dynamics, 11(4), pp.473-489.

Ranieri, R., 2011. Iron and Steel State Industry in the UK and Italy. In Reappraising StateOwned Enterprise. A Comparison of the UK and Italy. New York: Routledge.

Rosenstein-Rodan, P., 1961. Notes on the theory of the big-push. In H. C. Ellis, H.S., Wallich, ed. Economic development for Latin America. London: Macmillan. 
Rostow, W.W., 1990. The stages of economic growth: A non-Communist manifesto, Cambridge: Cambridge University Press.

Rotondi, C., Quadrio Curzio, A., 2015. Paradigmi per lo sviluppo italiano. Il contributo di Pasquale Saraceno. In Costabile, L., Lunghini, G., Quadrio Curzio, A., Roncaglia, A., Scazzieri, R., ed. Gli economisti italiani. Protagonisti, paradigmi, politiche. Roma: Bardi Edizioni.

Russolillo, F. ed., 2015. Storia dell'IRI. Settori, bilanci, presenza nell'economia italiana., Roma: Editori Laterza.

Sakong, I. \& Koh, Y., 2010. The Korean economy: Six decades of growth and development, Seoul: Korea Development Institute.

Samuelson, P.A., 1948. International trade and the equalisation of factor prices. The Economic Journal, 58(230), pp.163-184.

Sapelli, G., 1994. Economia, tecnologia e direzione d'impresa in Italia, Torino: Einaudi.

Saraceno, P., 1975. Il sistema della imprese a partecipazione statale nell'esperienza italiana, Milano: Giuffrè.

Saviotti, P.P. \& Pyka, A., 2004. Economic development, qualitative change and employment creation. Structural Change and Economic Dynamics, 15(3), pp.265-287.

Scazzieri, R., 2009. Structural Economic Dynamics: Looking Back and Forging Ahead. Economia Politica, 26(3), pp.531-558.

Scazzieri, R. \& Witt, U., 2005. Approaches to production theory. Structural Change and Economic Dynamics, 16(2), pp.159-163.

Sen, A., 1960. Choice of Techniques, Oxford: Basil Blackwell.

Shin, D.-H., 2007. A critique of Korean National Information Strategy: Case of national information infrastructures. Government Information Quarterly, 24(3), pp.624-645. 
Silva, E. \& Teixeira, A., 2008. Surveying structural change: Seminal contributions and a bibliometric account. Structural Change and Economic Dynamics, 19(4), pp.273-300.

Siniscalco, D., 1988. Beyond manufacturing: structural change, service sector employment and foreign trade in the Italian economy, 1960-1985. Available at: http://search.lib.cam.ac.uk/?itemid=|cambrdgedb|1071179.

Sohn, E., Chang, S.Y. \& Song, J., 2009. Technological Catching-up and Latecomer Strategy: A Case Study of the Asian Shipbuilding Industry. Seoul Journal of Business, 15(2), pp.25-57.

Song, Y.-I., Lee, D.H., Lee, Y.G., Chung, Y.C. 2007. Managing uncertainty and ambiguity in frontier R\&D projects: A Korean case study. Journal of Engineering and Technology Management, 24(3), pp.231-250.

Spaventa, L., 2013. Dualism in economic growth. PSL Quarterly review, 66(266), pp.201-253.

Spaventa, L., 1960. Problems of Intermediate Stages of Growth. The Economic Weekly, 12(27), pp.1077-1082.

Stern, J., 1995. Industrialization and the State: The Korean Heavy and Chemical Industry Drive, Cambridge, Mass.: Harvard University Press.

Stiglitz, J.E., 1989. The economic role of the state A. Heertje, ed., Oxford: Basil Blackwell.

Timmer, M.P. \& Szirmai, A., 2000. Productivity growth in Asian manufacturing: the structural bonus hypothesis examined. Structural Change and Economic Dynamics, 11(4), pp.371392.

Toninelli, P.M. ed., 2011. The Rise and Fall of State-Owned Enterprise in the Western World, Cambridge, UK; New York: Cambridge University Press.

Toniolo, G., 2013. The Oxford Handbook of the Italian Economy Since Unification, New York: Oxford University Press.

Verspagen, B., 1991. A new empirical approach to catching up or falling behind. Structural Change and Economic Dynamics, 2(2), pp.359-380. 
VV AA, 1981a. Annali dell'economia italiana, 1953-1958. Il ritorno sui mercati mondiali, Milano: Istituto IPSOA.

VV AA, 1981b. Annali dell'economia italiana, 1971-1977. Gli anni del "go and stop," Milano: Istituto IPSOA.

Witt, U., 2003. Economic policy making in evolutionary perspective. Journal of Evolutionary Economics, 13(2), pp.77-94.

Zamagni, V., 1990. Dalla periferia al centro. Bologna: Il Mulino.

Zamagni, V., 1993. The economic history of Italy, 1860-1990, Oxford: Clarendon Press. 